\title{
Association between insulin resistance with UCP2 -866G/A, UCP2 45BP INS/DEL, UCP3 -55C/T, GHSR1A RS2922126, GHSR1A RS509035 and PRO12ALA PPART2 gene polymorphisms in obese female adolescents in Yogyakarta, Indonesia
}

\author{
Rina Susilowati ${ }^{{ }^{*}}$, Dian Eurike Septyaningtrias ${ }^{1}$, Cut Gina Inggriyani ${ }^{1}$, Harry Freitag Luglio Muhammad ${ }^{2}$, \\ Madarina Julia ${ }^{3}$
}

From 7th APPES Biennial Scientific Meeting

Nusa Dua, Bali. 14-17 November 2012

\begin{abstract}
Aims
The aim of this study was to analyze the association between polymorphism of several genes encoded the uncoupling proteins (UCPs), ghrelin receptors (GHSRs) and peroxisome proliferator-activated receptor gamma (PPAR $\gamma$ ) with insulin resistance in obese female adolescents in Yogyakarta, Indonesia.
\end{abstract}

\section{Methods}

Screening for obesity using CDC 2000 criteria was done in 2121 female adolescents aged 13-14 years old in Yogyakarta. BMI $>95^{\text {th }}$ percentile was considered as obese. Among the obese subjects, 78 agreed to be enrolled for this study. HOMA-IR > 3.16 was used to determine the insulin resistance status. DNA was isolated from peripheral blood and UCP2 -866 G/A, UCP3 $-55 \mathrm{C} / \mathrm{T}, \mathrm{GHSR} 1 \mathrm{a}$ rs2922126, GHSR1a rs509035 and Pro12Ala PPAR $\gamma 2$ genotypes were analyzed by PCRRFLP. UCP2 45bp ins/del genotype was analyzed by PCR.

\section{Results}

Among the 78 obese adolescent girls, 44 (56.4\%) were at insulin resistance state. All subjects had Pro12Pro

'Department of Histology and Cell Biology, Faculty of Medicine Universitas Gadjah Mada Jalan Bulaksumur, Indonesia

Full list of author information is available at the end of the article
PPAR $\gamma 2$ and del/del UCP2 genotype. Compared to the other polymorphisms analyzed in this study, the AA genotype and the A allele of UCP2 -866 G/A polymorphism was found to have highest association with insulin resistance state (OR: 2.75 ; 95\% CI $0.65-11.62$; $\mathrm{p}=0.17$ for AA genotype; OR 1.50; 95\%; CI $0.79-2.83$; $\mathrm{p}=0.22$ for A allele). In UCP3 $-55 \mathrm{C} / \mathrm{T}$ polymorphism, TT genotype also showed positive statistically not significant association with insulin resistance (OR 2.32; 95\% CI 0.38 - 14.12; $\mathrm{p}=0.36$ ), so did $\mathrm{T}$ allele (OR 1.30; 95\% CI $0.67-2.50$; $\mathrm{p}=0.45)$. Genotyping of the Ghrelin receptor gene showed also non significant association with insulin resistance, i.e. the AA genotype (OR $2.25 ; 95 \%$ CI $0.21-24.4 ; \mathrm{p}=0.63$ ) and A allele (OR 1.05; 95\% CI $0.54-2.05 ; \mathrm{p}=0.89$ ) of the GHSR1a rs509035 polymorphism as well as AA genotype (OR 2.03; 95\% CI 0.54 - 7.57; $\mathrm{p}=0.28$ ) and A allele (OR 1.36 ; $95 \%$ CI $0.72-2.58 ; \mathrm{p}=0.34$ ) of the of the GHSR1a rs2922126 polymorphism.

\section{Conclusion}

We observed not statistically significant association between gene polymorphism of UCP2 -866G/A, UCP3 $-55 \mathrm{C} / \mathrm{T}$, GHSR1a rs509035, GHSR1a rs2922126 and the incidence of insulin resistance in obese female adolescent in Yogyakarta Indonesia. 


\section{Authors' details}

${ }^{1}$ Department of Histology and Cell Biology, Faculty of Medicine Universitas Gadjah Mada Jalan Bulaksumur, Indonesia. ${ }^{2}$ Department of Health Nutrition, Faculty of Medicine Universitas Gadjah Mada Jalan Bulaksumur, Indonesia. ${ }^{3}$ Department of Child Health Faculty of Medicine Universitas Gadjah Mada Jalan Bulaksumur, Indonesia.

Published: 3 October 2013

doi:10.1186/1687-9856-2013-S1-036

Cite this article as: Susilowati et al: Association between insulin resistance with UCP2 -866G/A, UCP2 45BP INS/DEL, UCP3 -55C/T, GHSR1A RS2922126, GHSR1A RS509035 and PRO12ALA PPART2 gene polymorphisms in obese female adolescents in Yogyakarta, Indonesia. International Journal of Pediatric Endocrinology 2013 2013(Suppl 1):036.

Submit your next manuscript to BioMed Central and take full advantage of:

- Convenient online submission

- Thorough peer review

- No space constraints or color figure charges

- Immediate publication on acceptance

- Inclusion in PubMed, CAS, Scopus and Google Scholar

- Research which is freely available for redistribution

Submit your manuscript at www.biomedcentral.com/submit 